\title{
Legal and practical aspects of bankruptcy proceedings in Albania and their role in the protection of stakeholders
}

\author{
Blerta Aliu \\ European University of Tirana \\ baliu@uet.edu.al
}

\begin{abstract}
Bankruptcy represents an effort to find the correct ratio between the need to protect economic assets left over from a subject in crisis and need to take care and realize greater extent the rights of creditors. Bankruptcy in Albania, for the first time was adjusted in the Commercial Code of Zogu, " Book six - Bankruptcy". Today in the Republic of Albania the law in 2002 "On bankruptcy" amended by law in 2008. This law is largely a continuation of adjustments made in 1995. This paper will address the news that the new law brings, regarding the procedures to be followed and the conditions to be met for a person debtor, can be downloaded from the remaining obligations. Regulated recognition of a foreign bankruptcy procedure and the opening of a secondary procedure, as well as collaboration between the higher of the two bankruptcy proceedings. Also, according to recent changes have envisaged by the law, Bankruptcy Supervision Agency" which is a public legal entity. We will treat the compatibility of our legislation with EU Regulation of 2000. The methodology used in the paper is the analysis of legislation and practical decisions. The conclusions show a positive tendency of legal norms to protect creditors, but the level of jurisdiction decisions and practice seems more embryonic. Relevance of this topic is related to social, legal but also economic aspects.
\end{abstract}

Keywords: companies, bankruptcy, credit line, agency surveillance, territorial competence.

\section{Introduction}

Bankruptcy law ${ }^{1}$ is a barometer of the two biggest changes that affected Europe in the late twentieth century: the consensus in favor of market economy and the need to control unemployment. Regarding the main purpose of bankruptcy, in world literature there are different views about this item.

Supporters of the classical theory, say that the aim all procedures in the process of bankruptcy is willingness to realize the right of creditors to an enterprise in crisis, for equality of treatment as regards their execution undertaken that is compelled by the state of insolvency of the company (debtor) in crisis. According to modern views and trends that present bankruptcy legislation today, the purpose of bankruptcy proceedings is the elimination from the market of enterprises (companies) in crisis when their business continuity results not productive for the economy in general. (K. Katro, 2004)

The way companies are managed, in the world of today represent a broad spectrum of regulations that revolve around corporate governance, which often emphasize the importance of guaranteeing stakeholders affected by the proper management. The purpose of this paper is to shed an overview on some specific aspects of bankruptcy in Albania, dealing with how a debtor entity protected creditors front.

Methodology found in this paper includes qualitative methods of analysis of legal provisions, contemporary literature of different authors, as well as analysis of judicial practice. Central hypothesis in this paper is related to the Albanian legal framework, which is of a high standard, but that does not come in straight line with the case law and effective enforcement in protecting stakeholders.

Below, we will discuss, first, the historical evolution of bankruptcy legislation in Albania, in addition, some international standards in this field, further, the current legal approach to them and in the end, the Albanian judicial practice in this area.

\footnotetext{
${ }^{1}$ For “Mbi zbatimin e ligjit të Falimentimit”, Tiranë 1999, fq 77-83. see K.Katro, 2004
} 
ISSN 2411-9563 (Print) ISSN 2312-8429 (Online)
European Journal of Social Sciences Education and Research
September-December 2014

Volume 1, Issue 2

\section{Historical developments on Bancruptcy in Albania}

The historical overview for bankruptcy and its origin, shows that Europe is divided into three main currents ${ }^{1}$. In fact, these aspects have an impact on each other, especially the Napolonik direction has influenced the Romanic one, but they still make different regulations .

Albanian legislation bankruptcy since 1995, enters the Germanic trend, if not that current law makes similar arrangements with German law. The first Albanian law of bankruptcy in Albania is Zogu "Book VI of the Commercial Code "2 and all the rest of the Zogu's commercial legislation is based on the Italian Commercial Code, of 1882. (K. Katro 2004) Bankruptcy and privatization are different institutions, with their own objectives and procedures, and in many cases former state enterprises are simultaneously subject to two procedures. State enterprise can restructure through _ bankruptcy type (state-owned enterprises that survived the procedures stipulated by law of 1992) and then to privatize.

After the changes in '90 for the first time after a very long period, bankruptcy is regulated by Law no. 7631, date. 29.10.1992, "On Bankruptcy of State Enterprises." He had a total of 40 articles. This law stipulated that a single procedure can lead to the rehabilitation of the company or its liquidation. Thus, in Chapter II predicted the possibility of a reorganization agreement so that it can be preserved subject and can be verified if there was a possibility that the company extracted from insolvency.

The only obligation of the state rose after the liquidation of the enterprise, to laid off employees, but the obligation, although projected in bankruptcy law33, belonged to a relationship that was regulated by another law, he "For social support for unemployed persons arising from the implementation of economic reform "4.

\section{International developments on Bancruptcy in Europe}

On a study in 2004, the European Bank for Reconstruction and Development (EBRD) completed two major insolvencyrelated studies: the Insolvency Sector Assessment (ISA) and the Legal Indicator Survey on Isolvency (LIS). Bancruptcy and insolvency legal systems are often incorrectly thought to be solely about helping creditors recover loans made to debtors. In fact, these legal systems encapsulate a number of commercial,social and political values of society. The methodology of the assessment involved constructing a list of 97 fields of inquiry, created using the most widely accepted international standards adopted by World Bank and the United Nations Commission on International Trade and Law, among others. These fields were grouped into the five core areas:-commencement of proceedings;-treatment of estate assets; treatment of creditors;-reorganization processes; and -terminal liquidation processes. (M Uttamchandani, EBRD 2004). In virtually every case, practitioners in each country were to verify the assessments of the EBRD experts. In the end, a final numerical score was assigned to each country and the countries were then grouped according to their level of compliance with international standards, ranging from "very high" down to "very low", as illustrated in table 1. (2004 10 JIBLF, page 15)

\footnotetext{
1 The currents, according to Piero Pajardi 1998 have been: 1 - The Romanik, who backs in Roman law and Italian law where legislation includes Italian Belgian Spanish Luxembourg; 2 - Napolonike which relies heavily on the Napoleonic Commercial Code and in French bankruptcy legislation which include Greek, Portuguese, etc.; 3 - Germanic which is based in the German bankruptcy legislation which include legislation, Danish German Dutch Austrian, etc.. K. Katro, 2004
}

${ }^{2}$ Zogu's Commercial Code " The Sixth book _ - Bankruptcy; under this law the trader was considered in the state of Bankruptcy when dismiss the payments made for obligations (liabilities) of his trade. The particular of the law of Zogu's was that predicted that within 24 hours of receipt of the decision to declare bankruptcy for _ specific trade the chief judge shall transmit to the State Attorney copy of the sentence, and all relevant information for which the court has been informed. The prosecutor was obliged to investigate whether there were elements for the criminal proceeding. Even if for the debtor was initiated a criminal proceeding, bankruptcy procedures continued uninterrupted. Thus two procedures kept independent of each. This law as general Bankruptcy legislation, he put all creditors in the same position but it create _ sequence preference. K. Katro 2004.

${ }^{3}$ Law nr. 7631, dt. 29.10.1992 "Për falimentimin e ndërmarrjeve shtetërore", article 39.

${ }^{4}$ Lae nr. 7521 dt. 30.10.1991, ndryshuar me Ligjin nr. 7579, dt.02.07.1992 "Për përkrahjen sociale për personat që dalin të papunë nga zbatimi i reformës ekonomike" 
Table 1: The Level of legislative compliance with international standards and best practices of insolvency

\begin{tabular}{|l|l|l|l|l|}
\hline $\begin{array}{l}\text { Very Low } \\
\text { compliance }\end{array}$ & $\begin{array}{l}\text { Low } \\
\text { Compliance }\end{array}$ & Medium Compliance & High Compliance & $\begin{array}{l}\text { Very High } \\
\text { Compliance }\end{array}$ \\
\hline Lithuania & Azerbaijan & Armenia & Albania & \\
\hline Tajikistan & Georgia & Belarus & Bosnia and Herzegovina & \\
\hline Turkmenistan & Hungary & Czech Republic & Bulgaria & \\
\hline Ukraine & Latvia & Estonia & Croatia & \\
\hline & Slovenia & Kazakhstan & Moldova & \\
\hline & Uzbekistan & Kyrgyzstan & Romania & \\
\hline & & Macedonia & Serbia and Montenegro & \\
\hline & & Poland & & \\
\hline & & Russian Federation & & \\
\hline & & Slovak Republik & & \\
\hline
\end{tabular}

\section{Table 1: Butterworths Journal of International Banking and Financial Law-December 2004}

On international terms has been continuous efforts in Europe to bankruptcy problems ${ }^{1}$.Thus, the EU Regulation ${ }^{2}$ on bankruptcy procedures is expressed for automatic recognition of the foreign judgment to the start of bankruptcy, and this is reflected in German law (Sections 335-338 of the Ins-os).

On the EU Regulation on bankruptcy procedures reciprocity is ensured, because each member state is obliged to recognize the decision to start the procedure of bankruptcy of another member state.

On contrast, Swiss law provides as a condition of recognizing the existence of reciprocity (Article 166, paragraph 1, letter ce IPRG), but the majority of Swiss authors criticize such a solution to Swiss law making efforts to alleviate this through interpretations in different ways ${ }^{3}$..

EU Regulation concerning jurisdiction gives courts of the Member State in whose territory the debtor has the center of its main interests, the power to initiate bankruptcy proceedings.

How is defined "the center of main interests"? Explanatory notes of Regulation protects the principle of Virgos Schmit Convention of 1995, according to which the concept of the place where the debtor corresponds regularly administers its interests, the country which is recognized by third parties.

However, there is conflicting tendencies, when, if we refer to the fact that the main bankruptcy proceedings includes all the debtor's assets in each member state, which means that there is overlap with the assets that must be managed in a secondary bankruptcy process, who has territorial force in another state, after the main proceedings is applicable where the secondary procedures has started

\footnotetext{
1 In 5 June 1990 in Istanbul was the current European Conventions on "Some International Aspects of Bankruptcy" which was asigned only by eight countries of which only one has ratified. In 1995 the European Union adopted a Convention on Insolvency Proceedings. None of these conventions have entered into force. European Convention on Certain International Aspects of Bankruptcy
}

${ }^{2}$ Regulation was adopted in 29 May 2000 and entered into force in EU member states_May 31, 2002. Council Regulation on Insolvency Proceeding (CE), N. 1346/2000, dt.29.05.2000.

3 Simpoziumi i Ohrit, fq 63, K Katro, 2004 
Article 33 is one of the practical rules of hierarchy that enables operation between bankruptcy proceedings. So, according to it, the liquidator (administrator) of the main procedure of bankruptcy requires to the court, who has open secondary bankruptcy proceedings, suspension of the latter.

The law applicable is , under Article 4 (1), each set of bankruptcy procedures governed by lex consursus or by the law of the Member State in whose territory procedures have started.

Lex Concurcus law is applicable to all matters dealt with in the bankruptcy process and their consequences. Regarding Labor contracts, employees are vulnerable party status during bankruptcy proceedings, so it would not be right to step their special protection under the election of law rules. The order of the employees' claims for unpaid wages under the contract shall be governed by the lex concursus. (P Torremans, 2004)

\section{Bankruptcy procedures after 2002 in Albania}

Bankruptcy law in 1995 defined a table of priorities specific to the bankruptcy procedure, clearly defining orders, determination underlying this procedure. Also, he had very definite actions objectionable, which clearly distinguished fraud standards, terms of visibility behind, although these were somewhat short.

Currently, the Republic of Albania is applicable the $2002^{1}$ law "On Bankruptcy". It is mainly a continuation of adjustments made in the previous law, but they are more detailed and filling gaps previously unnoticed. Law no. 8901 brings a new ninepart "Removal of the remaining liabilities", which includes procedures to be followed and the conditions to be met in order for a debtor person can be discharged from the remainder of its obligations.

A better arrangement than the previous law and in the spirit of Regulation 1346/2000 of the EU, made the current law in the Eleventh Part "bankruptcy procedure associated with other countries", which is regulated as a recognition of a foreign bankruptcy procedure _ (when the conditions provided for by law), and the opening of a secondary procedure, as well as the cooperation among higher bankruptcy structures among two open procedures.

An innovation that brings current Bankruptcy legislation is the fact that has envisaged "Bankruptcy Supervision Agency" which is a public legal entity. It operates in accordance with civil service legislation. The rights, duties and responsibilities they are defined in law.

The law provides that the request for the opening of a debtor's assets are insufficient to cover the costs of the bankruptcy proceedings ${ }^{2}$, costs which include court costs and the compensation and expenses of temporary Bankruptcy administrator, the Bankruptcy administrator and the creditors committee members (if any). So, it seems clear that the costs of the bankruptcy proceedings are the first order of obligations that must be met and even the fullest extent.

The law provides the fact that is respected the table of preferences set by Civil Code Article 605, with those changes that specifically provides Bankruptcy law. On this respect, the law provides that secured creditors are entitled to special repayment ${ }^{3}$, so staying if a sequence preference above other creditors, even by those eligible.

\section{Jurisprudence aspects of bankruptcy and the and the protection of stakeholders}

\section{The Regional Taxation Department against Eljo \& Co. in 2008, , about the competence of the Court}

In Albania, cases of conflict of jurisdiction between courts bring a practical case, where the Regional Tax Directorate, Dibër, sues the company Eljo \& CO. 2008 , and requires the opening of bankruptcy proceedings of this company, under Article $104^{4}$ of law "On Tax procedures in the Republic of Albania".

\footnotetext{
${ }^{1}$ Law nr 8901, dt 23.05.2002 "Për Falimentimin" shtuar dhe ndryshuar me ligjin nr. 9919, dt. 19.05. 2008 "Për disa shtesa dhe ndryshime në ligjin nr 8901, dt. 23.05.2002 "Për Falimentimin".

2 Law nr.8901, dt 23.05.2002 "Për Falimentimin", neni 18, pika 4,b.

${ }^{3}$ Law nr.8901, dt 23.05.2002 "Për Falimentimin", neni 41.

${ }^{4}$ The plaintiff has requested the initiation of bankruptcy after the verification results that this subject last 2 years from 2009 to 2010 did not carry any kind of activity verified this by DRT specialized services Dibër. Law No. 9920, dated 19.05.2008 "On Tax procedures in the Republic of Albania".
} 
ISSN 2411-9563 (Print) ISSN 2312-8429 (Online)
European Journal of Social Sciences Education and Research
September-December 2014

Volume 1, Issue 2

The respondent party is a limited liability company and operates in the District of Mat. Mat District Court, _ found a lack of competence to adjudicate the dispute ${ }^{1}$ and decided: "To declare its non the trial of this matter. But, as a rule, when the respondent is a legal person, the claims are raised at a locality court in where the legal person has its center. ${ }^{2}$

Moreover, the 2008 law defines so contradictory that "The bankruptcy proceedings is the duty of the commercial sections of the district court (the bankruptcy court)." In paragraph 3 of the same article stipulates that "review of issues should be made within 30 days of submission of the application to the secretary of the District Court, Tirana, commercial section." 3

Regarding territorial responsibility, bankruptcy procedures is reviewed at the commercial section of the district court where the debtor who is a person resides or headquarters. But if a bankruptcy is in the competence of some commercial district courts, the direct responsibility for the review adjudication of the case is for the commercial section of the district court where it was originally submitted the request for the opening of bankruptcy proceedings. Commercial section of the district court, which has responsibility for a bankruptcy judge, is the only court responsible for civil claims raised for bankruptcy ".

The High Court said that the decision, made by the District Court of Mat, was taken in the breach of the law and the matter is subject to review under the jurisdiction of the Administrative Section of the District Court Mat. The legislator, by a change of conduct in the 2008, has decided to add paragraph 3 of Article 3, which states: "Review of issues should be made within 30 days of submission of the application to the secretary of District Court of Tirana , the trade section ".

According to the Supreme Court this change shows a flagrant contradiction of its content not only with the general procedural provisions on territorial jurisdiction of the Civil Procedure Code but even with exhaustive arrangements of special provisions for the purpose of Articles 4 to 8 of the same law law No. 8901 dated 23.05.2002 "On Bankruptcy".

The High Court considered that if in the various laws or within the same law contained provisions that, contrary to each other provide different solutions on jurisdiction, in principle, the court dealing with the case follows the regulation which is in the harmony with the general procedure for determining the competent court in the the Albanian legal system increasingly in view of the forecast of tools as effective and efficient to the courts to administer justice.

\section{"Belle Air" Case and the protection of stakeholders}

In November 2013 persons who had purchased tickets to fly with Belle Air was announced through the media that the company with a sudden decision suspended all flights. Later Belle Air informed that those who seek to be reimbursed should be presented to the bank ( this applied only for those who had paid in the bank street) to pull the money. ${ }^{4}$

The decision to declare bankruptcy by company executives brought great damage to all passengers who in the terms of corporate social responsibility are considered one of the most important stakeholders in the This case. The Court of Tirana granted the request to open bankcruptcy proceedings for Belle Air ${ }^{5}$, despite conflicting facts that appear in the the way of its management.

The case is still pending, as is clear from the facts 6 that the shareholders and directors of the company according to NRC historical extract were members of the same family. Moreover the transactions made clearly reflect the company's management and hiding the abuses of its revenue. Finally in the response to aspects of social responsibility that corporations carry nowadays, the latter represents one of the most typical cases of violation of this responsibility.

\section{Conclusions}

\footnotetext{
${ }_{1}^{1}$ According to law No. 8901 dated 23.05.2002 "On Bankruptcy" specifically regulating this relationship, "Review of issues should be made within 30 days of submission of the application to the secretary of Tirana District Court of commercial section" (Article 3 made by the law). ${ }^{2}$ Article 43 of Albanian Civil Procedure Code

${ }^{3}$ Article 3 of law nr.8901, date 23.05.2002

4http://www.shqiptarja.com/ekonomi/2733/belle-air-mister-falimenti-i-nje-kompanie-miliardere-188752.html\#sthash.0mNMvFGj.dpuf

5 "Belle Air" company owned $55 \%$ of the market of aviation transport in Albania and 830 thousand passengers a year with a _turnover of 115 million euros a year; daily turnover of 315,000 euros. She owned a private bank debt to 8.5 million euro. Over the last 5 years, the company " " had not paid a fee of $\$ 10$ per ticket in the state budget. It should be added that the company has sold 55 thousand tickets to March 2014 taking advance money and consequently has received an amount of 8.5 million euros. found at:http://www.shqiptarja.com/ekonomi/2733/belle-air-mister-falimenti-i-nje-kompanie-miliardere-188752.html\#sthash.0mNMvFGj.dpuf ${ }^{6}$ http://www.qkr.gov.al/nrc/Kerko_Per_Subjekt.aspx
} 
Corporate governance is a system that interacts with different scientific profiles also with numerous components such as legal labor law, bankruptcy law, environmental law etc.. The concept of social responsibility is quite innovative in Albania but does not exclude recent trends to implement in different policies of the company . In the above submissions, it seems that the consequences of non-compliance with these concepts in the practice are quite harmful.

This work consisted in the examination of legal framework in Albania, seen in an evolving perspective and also thw current developments. Hereinafter, we took an overview of the international treatment of this topic and also, the approach and harmonization of Albanian legislation with the European one. In conclusion we bring practical illustration of two cases from the vague jurisprudence that exists in this field in Albania. In the first case there is a clash between the legal provisions of the current law _ on jurisdiction, of the court. While in the second case which constitutes one of the cornerstones in the history of Albanian companies, because of the economic importance of Belle Air, we brought some facts about bankruptcy procedure which is still in progress.

The protection of creditors of a company represents one more guarantee due to wider implementation of the concept of social responsibility of a company. Results of this study identify and ascertain the contemporary bankruptcy legal provisions however in some cases contradictory as is the case with the Supreme Court decision. Also there is a distinct lack of bankruptcy court decisions. According to statistics of the Court of Tirana the last 4 years ${ }^{1}$ have increased requirements for opening bankruptcy proceedings but it also found delays in completing the process.

\section{References}

[1] Butterworths Journal of International Banking and Financal Law- 10 JIBLF December 2004

[2] Council Regulation on Insolvency Proceeding (CE), N. 1346/2000, dt.29.05.2000.

[3] Gjykata e Tiranës, found at: http://www.gjykatatirana.gov.al/

[4] Http://www.shqiptarja.com/ekonomi/2733/belle-air-mister-falimenti-i-nje-kompanie-miliardere188752.html\#sthash.0mNMvFGj.dpuf

[5] Kestrin Katro- "E Drejta e Falimentimit", 2004, found at:

[6] https://www.google.al/?gws_rd=cr,ssI\&ei=_BfRU_ORDKaBywP1zoDABA\#q=kestrin+katro+falimentimi

[7] Kodi i Procedurws Civile found at:

[8] http://www.drejtesia.gov.al/files/userfiles/Legjislacioni/Kodi_i_Procedures_civile.pdf

[9] Ligji nr. 7631, dt. 29.10.1992 "Për falimentimin e ndërmarrjeve shtetërore"

[10] Ligji nr. 7521 dt. 30.10.1991, ndryshuar me Ligjin nr. 7579, dt.02.07.1992 "Për përkrahjen sociale për personat që dalin të papunë nga zbatimi i reformës ekonomike"

[11] Law No. 9920, dated 19.05.2008 "On Tax procedures in the Republic of Albania".

[12] Ligj nr.8901, datë 23.05.2002 "Për falimentimin", found at:

[13] http://ligjet.info/shoqerite_tregtare/falimentimi/ligje/8901

[14] Ligj nr. 9919, dt. 19.05. 2008 "Për disa shtesa dhe ndryshime në ligjin nr 8901, dt. 23.05.2002 "Për Falimentimin found at:

[15] http://mobile.ikub.al/LIGJE_CATEGORY/LIGJE/PeR-DISA-SHTESA-DHE-NDRYSHIME-Ne-LIGJIN-NR-8901DATe-23-5-2002-PeR-FALIMENTIMIN--805190001.aspx

[16] Paul Torremans, F.Tegu, A.Shehi-Falimentimi në Aspektin Krahasues" Shkolla e Magjistraturws, 2005.

[17] Piero Pajardi e autori vari, "Il falimento nel mondo", Padova 1988.

[18] Qëndra Kombëtare e Regjistrimit, found at

[19] http://www.qkr.gov.al/nrc/Kerko_Per_Subjekt.aspx

[20] Vendimi I Gjykates së Lartë, Nr 142, datw 15.03.2012 found at:

[21] https://www.google.al/?gws_rd=cr,ssl\&ei=rhnRU9imG8qGywPeolDoCg\#q=falimentimi\%2C+gjykata+e+larte

${ }^{1}$ http://www.gjykatatirana.gov.al/ 